\title{
At the Roots of Labour Activism: Chinese and Cambodian Garment Workers in Comparative Perspective
}

\section{Ivan Franceschini}

Australian Centre on China in the World, College of Asia \& the Pacific, The Australian National University, and Department of Asian and North African Studies, Ca' Foscari University, Venice.

Postal address: Australian Centre on China in the World, ANU College of Asia \& the Pacific, Building 188 Fellows Lane, The Australian National University, Canberra ACT 2601 Australia

Email: ivan.franceschini@anu.edu.au

\begin{abstract}
In China extensive, co-ordinated strikes such as those that have taken place in Cambodia in recent years remain rare, with most protests initiated by Chinese workers contained inside single factories or industrial zones. Also, while Cambodian workers often mobilise for their interests and broader policy issues, such as the determination of the minimum wage, Chinese workers largely limit themselves to protests against violations of their legal rights. How can these different patterns of labour activism be explained? Through factory gate surveys and interviews conducted during the summer of 2016 in a sample of Hong Kong-owned garment factories in Dongguan and Phnom Penh, this study provides a comparative analysis of the root causes of labour activism in China and Cambodia. In particular, the article focuses on three elements that play an important role in determining labour activism: the expectations of the workers regarding wages; the workers' perception of the labour law and the legal system; and trade union pluralism.
\end{abstract}

Keywords: China, Cambodia, labour protests, trade unions, labour law, wages

On December 24, 2013 tens of thousands of garment workers went on strike in Cambodia, demanding that the government double the minimum wage from US\$80 to $\$ 160$, much more than the $\$ 95$ that the authorities were willing to concede (The Phnom Penh Post, December 26, 2013; WRC 2014, 9-13). ${ }^{1}$ The mobilisation was launched by rank-and-file workers without instructions by union federations and lasted almost two weeks, paralysing the entire Cambodian industrial system, while trade unions, politicians, and business associations fired wild accusations at each other (AMRC 2014, 8). The deadlock was broken on the morning of January 3, 2014, when military police opened fire on the striking workers on Veng Sreng Boulevard, in the suburbs of Phnom Penh, killing five and injuring around 40 (The Phnom Penh Post, January 3, 2014; AMRC 2014, 21). This was not the first instance of massive, co- 
ordinated strikes in the Cambodian garment industry, and would not be the last. A few months later, in April 2014, 20,000 workers in a special economic zone in Bavet, Svay Rieng province, went on strike to claim a bonus that their colleagues in a neighbouring factory had received for not going on strike during the wave of protests of January 2014 (The Phnom Penh Post, April 28, 2014). Again, in December 2015, some 30,000 workers from 39 factories in three special economic zones in Bavet brought production to a standstill demanding that minimum wage increase to $\$ 148$ a month rather than the scheduled $\$ 140$ (The Phnom Penh Post, December 23, 2015).

As Arnold (2014 and 2017) has pointed out, Cambodian garment workers have repeatedly staged co-ordinated spontaneous protests on matters regarding their interests, in particular demands to increase the minimum wage. This represents a stark contrast with the pattern of activism in labour-intensive industries in China, where most labour protests remain unco-ordinated and limited to single workplaces and industrial zones, with the workers setting forth rights-based demands (Chan and Siu 2012; Lee 2007; 2016). ${ }^{2}$ Of course, the political system of the two countries is very different. While China is a Leninist one-party system dominated by the Chinese Communist Party (CCP), Cambodia has been labelled an "electoral authoritarian regime with pseudodemocratic elements" (McCargo 2005, 106), or a case of "competitive authoritarianism," defined as a "civilian regime in which formal democratic institutions exist and widely viewed as the primary means of gaining power, but in which incumbents' abuse of the state places them at a significant advantage vis-à-vis their opponents" (Levitsky and Way 2010, 5). Still, Chinese and Cambodian authorities both preside over very repressive environments and have repeatedly used force to suppress labour unrest. If workers in both countries face dire consequences for mobilising, why are the patterns of labour activism so different? To respond to this question, this article will focus on three elements that play a fundamental role in shaping the workers' proclivity to organise: 
workers' needs and expectations towards wages; the different level of saturation of official discourses of labour rights promoted by the authorities; and the existence - or lack of - union pluralism. While there are other factors at play in determining the different patterns and significant local variations (especially in China), these three aspects represent an important starting point for a better understanding of the different patterns of labour organising in the two countries.

For the sake of clarity - and to avoid undue generalisations - this analysis will focus exclusively on the garment sector. This choice was basically unavoidable, as this industry along with tourism and construction - is the main pillar of the Cambodian economy, employing more than 600,000 workers and accounting for as much as $80 \%$ of the country's total merchandise exports (ILO 2017). While labour exploitation is common in many other sectors - and while Chinese and Cambodian workers in other industries have not refrained from engaging in protests - the garment sector remains an important focus of labour discontent in both countries. In China, one has only to think about the massive protests that erupted in 2014 at Yue Yuen, a huge footwear company based in Dongguan, Guangdong province, when tens of thousands of workers went on strike to demand the payment of their social security contributions (Schmalz, Sommer, and Xu 2017). In Cambodia, this restlessness can be seen not only in the number of strikes that made the headlines in the national press over the past few years, but also, indirectly, in the attention that Prime Minister Hun Sen has dedicated to garment workers in electoral campaigning for the 2018 national elections. In August 2017, he started holding weekly meetings with garment industry employees in various industrial zones around the Cambodian capital. He also promised that workers would get free health care, free access to public transport in Phnom Penh and a significant minimum wage increase if his party won (The Phnom Penh Post, August 21, 2017). 
While there is also a growing body of literature that put Chinese labour in a comparative perspective (see Chan 2016), this article represents the first comparative study of Chinese and Cambodian garment workers. Although the two countries are occasionally juxtaposed in discussions of global investment trends - sometimes to say that garment industries are leaving China to move to countries like Cambodia, where labour is cheaper, and sometimes to say the opposite, that labour unrest in Cambodia is scaring away investors in favour of other more stable countries, including China - no comparative study of Chinese and Cambodian labour issues has been completed. Most literature on Cambodian labour focuses on the nexus between export-oriented garment manufacturing and labour rights (see, for example, Chiu 2007; Kolben 2004; Polaski 2006). Only occasional forays have been made into the realm of garment workers' voice and agency (Arnold 2014 and 2017; Derks 2008; Ward and Mouyly 2016). This article is the first effort to "quantify" subjective matters such as the expectations of Cambodian garment workers in matters of wage and work hours, as well as their knowledge and perception of the labour law. Chinese labour, on the contrary, is the object of a wide-ranging literature that covers the topic from almost every angle. Not only is there no lack of studies dedicated to the agency of Chinese garment workers (Chan and Siu 2010 and 2011; Fan 2016; Siu 2017), but China scholars have also investigated issues related to the subjectivity of Chinese workers. Several studies investigate how Chinese workers perceive the labour law and the legal system (Gallagher 2006 and 2007; Gallagher and Wang 2013; Gallagher and Yang 2017; Wong 2011); attempt to assess the workers' expectations in terms of wages and labour conditions (Chan and Siu 2010 and 2011; Franceschini, Siu, and Chan 2012); or look into how the party-state attempts to promote the labour law as a "hegemonic discourse" aimed at controlling and channelling workers' demands (Blecher 2002; Cheng 2017; Hui 2016a, 2016b, and 2017). It is this literature that this article engages. 
The research for this article combines quantitative and qualitative methods. During the summer of 2016, two surveys were conducted, aimed at assessing the expectations of Cambodian and Chinese garment workers in terms of salaries and labour conditions, as well as their perception of the law and the trade unions. The first survey was conducted in June and July 2016 at three garment factories owned by Hong Kong companies in Dongguan, Guangdong province in China's south. These factories employed 2,000, 1,000, and 800 workers, and in each one of them respectively 120, 90, and 40 questionnaires were collected, for a total of 250 questionnaires. The second survey was carried out from July to September 2016 in three Hong Kong-owned garment factories in Phnom Penh, where the garment industry is concentrated. In this case, the factories employed 5,700, 2,100, and 1,100 workers, and in each one of them respectively 130,121 , and 40 questionnaires were collected, for a total of 291 questionnaires. To avoid interference from the management and possible biases in the responses of the workers, no permission was sought from the factory and precautions were taken to ensure the anonymity of the interviewees. All respondents were approached outside the factory, most often in their accommodation after their shift had ended or in restaurants around the factory during their lunch break. In Cambodia, these quantitative data were then integrated with 20 semi-structured interviews with garment workers employed in the sampled factories, as well as additional interviews with local lawyers specialised in labour disputes, leaders of independent unions and labour NGO activists. In China 20 semi-structured interviews were conducted with garment workers in the sampled factories, complemented by dozens of interviews with labour activists based in Guangdong province collected since 2009.

The choice of focussing on Hong Kong-owned factories was motivated by the economic relevance in both countries of the investments coming from the former British colony. In 2016, entrepreneurs from Hong Kong not only represented the second largest group of new investors in the Cambodian garment sector, right after their mainland Chinese 
counterparts (ILO 2017), but they were also the largest source of overseas direct investment in mainland China (Hong Kong Trade Development Council 2017). The factories in the sample were chosen on the basis of three criteria: (i) their location - they had to be located in the same administrative area, especially in China, where minimum wages varies from city to city; (ii) their size - the factories in the two countries had to be roughly comparable in terms of number of employees; and (iii) access to the workforce - since the survey was conducted without any prior knowledge of the management, it was important to choose factories with accessible worker accommodations close by. Also, it is important to underline that the research focussed on factories that were formally licensed, not on unregistered subcontracting workshops where labour conditions are notoriously worse. In this sense, while the sample offers a good overview of the situation in the garment industry in the two countries, it does not take into account those semi-legal or illegal realities where abuses of labour rights are even more common.

This article is in five sections. First, it describes the sample, highlighting differences and commonalities between the Chinese and Cambodian workforce. Second, it considers the wages in the garment industry in the two countries, comparing the salaries workers are entitled to, those that they actually get, and those that they desire. Third, it outlines the different rationales that led the Chinese and Cambodian authorities to adopt a labour legislation and analyses how workers relate to these laws and to the legal system. In a fourth section, the article considers how workers perceive the unions and how they feel about strikes. In a final section, some general conclusions are drawn.

\section{SETTING THE SCENE}

Due to its low capital requirements, limited automation and minimal demands in terms of skills, the garment industry is an ideal start-up industry for any economy with a large 
unskilled workforce and bare financial and logistical infrastructure. Still, these very elements make the industry highly susceptible to fluctuations in the cost of labour, rendering it unsuitable for more developed economies. This unsuitability is particularly apparent in the case of China. After four decades of "reforms and opening up," China remains the undisputed global leader in the garment sector, with its 2016 exports worth as much as \$253 billion (WITS 2018a). There are, however, already signs that its garment industry is unravelling due to rising labour costs as the country embarks on an ambitious path of industrial upgrading (Van Der Kamp 2016). In contrast, the Cambodian garment sector was established only recently - the first garment factories appeared only in 1994, when Cambodia finally began to emerge from more than two decades of chaos and guerrilla warfare - and maintains a positive outlook (Arnold and Shih 2010). Having started from barely $\$ 80$ million in exports in 1996, in 2015 the Cambodian garment sector had become a $\$ 6.8$ billion industry, the ninth largest in the world after China, the European Union, Bangladesh, Vietnam, Hong Kong, India, Turkey and Indonesia (ILO 2017). More importantly, while the garment industry today occupies a relatively minor part of the Chinese economy - in 2016 only $12 \%$ of the Chinese merchandise exports were in the textile garment sector (WITS 2018b) - Cambodia's economic growth remains heavily dependent on garments, with about 610,000 workers employed in the sector in 2016 and as much as $80 \%$ of the country's total merchandise exports over the same year being garment and footwear products (ILO 2017).

In spite of their different size and significance for the domestic economy, the Chinese and Cambodian garment industries have one important factor in common: a large pool of unskilled rural labourers willing to move to the cities and toil in factories. There are, however, some fundamental demographic differences between the two workforces. While the garment sector in both countries employs mostly younger women from the countryside, generally viewed by employers as docile and apt at sewing, since the early 2000s coastal areas in China 
- including Dongguan - have been hit by cyclical "labour shortages" that have forced employers to be less picky (Zhang and Liu 2012). With many young Chinese rural women deciding to stay home to raise a family or to look for a job in townships closer to their hometowns, factories find it increasingly difficult to recruit young female workers, so they have to hire older women or even men (Siu 2017). In Cambodia, on the contrary, $87 \%$ of garment workers are female (ILO 2017). The survey sample for this study reflects this trend, with only $74 \%$ of the Chinese sample composed of women, compared to $91.7 \%$ in Cambodia. That a shift in the employment pattern is taking place in China is also suggested by the fact that the workers in the Chinese sample were older, with half of them born before 1980 compared to $8.6 \%$ of their Cambodian counterparts - and only $6.4 \%$ born in the $1990 \mathrm{~s}-$ compared to $41.9 \%$ in Cambodia. This age gap translates in a higher percentage of married workers in China - 95.2\% compared to $57.7 \%$ in Cambodia - and in a higher percentage of Chinese workers with children $-98.8 \%$ compared to $52.2 \%$ in Cambodia. It also means that Chinese workers have a longer migration history: while $45.8 \%$ of the Chinese workers had left their rural hometowns at some point in the 1990 s and $46.6 \%$ in the 2000 s (the others had migrated in the $2010 \mathrm{~s}$ ), $58.8 \%$ of the Cambodian workers had left the countryside after 2010 .

Almost all workers in both samples came from the countryside, but there is a fundamental difference between the two workforces. While most workers in the Chinese sample are second-generation migrants, in Cambodia the vast majority comes from families without any previous experience of migration. More specifically, 53.1\% of the sampled Chinese workers had at least one migrant parent - with $41.1 \%$ of the whole Chinese sample declaring that both parents had been migrants - compared to only $4.5 \%$ in Cambodia. This is easily explained, if we consider that China begun its economic reforms in the late 1970s and Cambodia's industrial base re-emerged from the ruins of civil war only in the mid-1990s. That Cambodia is lagging behind China in terms of social development emerges also from the 
data on education. While $77.8 \%$ of the sampled Chinese workers had attended middle school or above, only $44.3 \%$ of the Cambodian workers had attained the same level of education, the others having only an elementary education or not even that. Significantly, $4.8 \%$ of the Cambodian workers were illiterate, none of the Chinese was.

Another factor worth considering is employment status. The workforce in both countries appears to enjoy formal employment. First, almost all of them $-99.2 \%$ in China and $86 \%$ in Cambodia - had been hired directly by the company, with only a tiny minority of interns and, in a few cases, dispatch-workers. Second, all workers in the Chinese sample had signed a written labour contract, compared to $67.7 \%$ of the workers in Cambodia, where an additional $30.9 \%$ claimed to have an oral contract, a possibility allowed by the national legislation. Still, this does not mean that these workers were not living in a precarious situation. Although medium to long-term employment is a common occurrence in the garment industry in both countries $-36.8 \%$ of the workers in the Chinese sample and $46.7 \%$ in the Cambodian sample had worked in the same factory for more than three years - fixed-term contract were the norm, with $88.3 \%$ of the workforce in China and $65 \%$ in Cambodia hired on these terms. The important difference was that in China the average length of a fixed-term contract was around three years, in Cambodia it was only six months. This finding reflects how the Cambodian garment industry has shifted from a reliance on open-end contracts in the mid-1990s, when the Cambodian authorities attempted to gain a competitive advantage over lower-cost competitors by projecting a worker-friendly image to western buyers, to a widespread use of short-term contracts, a situation made possible by some ambiguities in the interpretation of the Labour Law (Yale Law School 2011). Nevertheless, although the majority of Cambodian workers were subjected to this form of extreme precariousness, $33.6 \%$ of them had a permanent contract with the company, a finding that suggests the existence in Cambodian garment factories of a "labour force dualism" (Zhang 2015) accompanied by 
slight differences in the economic treatment, as the permanent workers in my survey on average received a take-home wage of $\$ 260.71$ a month, compared to the $\$ 234.94$ of their non-permanent counterparts.

In sum, compared to their Cambodian counterparts, the Chinese workers in the sample were older, better educated, and had a history of migration that often extended to the generation of their parents. A larger percentage of them had children to worry about and their employment was relatively more stable, with a prevalence of fixed-term contracts of three years. On the contrary, Cambodian workers were younger and less educated, the vast majority of them coming from families that had not had any previous experience of industrial work. While they were subjected to extreme precariousness, with labour contracts up for renewal every six months, overall they spent a longer time working in the same factory - which means that these contracts were very likely to be extended - and in several cases had even been granted a permanent position, something that rarely happens in China. In other words, although for different reasons, workers in both countries had much at stake when considering whether to pick up a quarrel with their employers.

\section{WAGES: REALITY, EXPECTATIONS, AND NEEDS}

Working in a garment factory can be an exhausting experience. The Chinese workers in the sample worked an average of 10.3 hours a day from Monday to Friday, plus an average of 9.9 hours on Saturdays with only Sundays off. This is a violation of the national labour law, which states that workers should work no more than eight hours a day and 44 hours a week on the average, with a maximum of 36 hours of overtime a month. In Cambodia, the workers on average laboured 9.7 hours a day from Monday to Saturday and got only one day 
off every two weeks, another violation of the national legislation, which allows 48 hours a week, with no more than two hours of overtime a day. That the workload was perceived as excessive was made abundantly clear by the fact that, when asked how many hours they would have like to work in order not to impair their health, workers in both countries indicated around 9 hours ( 9.1 hours in China and 9 hours in Cambodia), with four days of rest a month (3.9 in China and 3.4 in Cambodia). Still, overtime was not considered a problem per se, as it was perceived as the only viable way to increase an otherwise meagre salary. When asked whether they would still have been willing to work overtime in a situation in which their salary was enough to cover their life expenses, $51.4 \%$ of the Chinese workers said yes, compared to $90.7 \%$ of the Cambodian workers, a disparity which might be related to differences in the payment system, with the majority of the workers in China (90.8\%) paid by piece-rate - a much more exhausting arrangement than time rate - and $72.8 \%$ of the Cambodian workers by time rate (on the difference between time rate and piece rate, see Franceschini, Siu, and Chan 2016).

While protests related to long work hours remain rare in China and Cambodia, wages remain a major reason of worker discontent in both countries. Figures 1 and 2 allow us to compare the workers' take-home wage with the wage they desire and the wage they need. The first column in the figures shows the minimum wage at the time of the survey. In China, local governments can decide their own monthly minimum wage and in Dongguan during the summer of 2016 it was set at 1,510 yuan (roughly \$226.85). Until recently, in Cambodia only the garment and footwear sector was covered by a minimum wage, which at the time of the survey the government had set at $\$ 140$ per month, the same figure for all the country. ${ }^{3}$ The Cambodian minimum wage is decided by the government on the basis of the recommendation coming from a tripartite Labour Advisory Committee composed of 28 representatives, 14 from the government, seven from the employers' associations, and seven from the unions 
(five of whom are staunch supporters of the ruling party). Significantly, while in China there are no reported strikes related to minimum wage, in Cambodia minimum wage remains a controversial issue. As mentioned above, in early January 2014 massive strikes and demonstrations of garment workers protesting over the government's refusal to raise the minimum wage ended after the intervention of the military police. Although in the following years there were no more demonstrations during the minimum wage negotiations, the raises that were granted by the government always fell far short of the expectations of independent trade unions and workers. In 2016, for instance, independent unions pushed for a new minimum wage of no less than $\$ 171$ (up from $\$ 140$ ), but the government settled on a figure of $\$ 153$, far closer to the $\$ 147$ proposed by the employers' association (The Phnom Penh Post, September 30, 2016). This was far below the $\$ 177$ that some local and global trade unions and advocacy groups had been demanding as a "living wage" for Cambodian garment workers since 2014 (Clean Clothes Campaign 2015).

Wage and Perceived Needs per Month in China (in US\$)

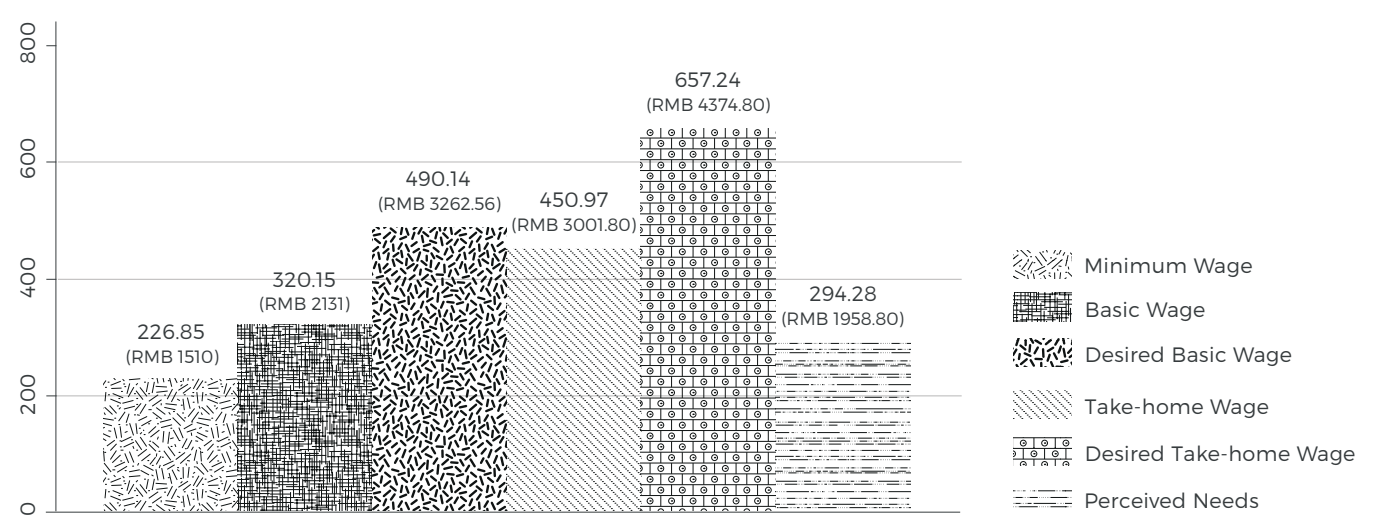

Figure

\section{Wage and Perceived Needs in China, 2016}


Note: US\$ rates with corresponding amount in RMB, calculated on the basis of the exchange rate on July 3, 2016 according to www.oanda.com.

Source: Author's surveys.

Wage and Perceived Needs per Month in Cambodia (in US\$)

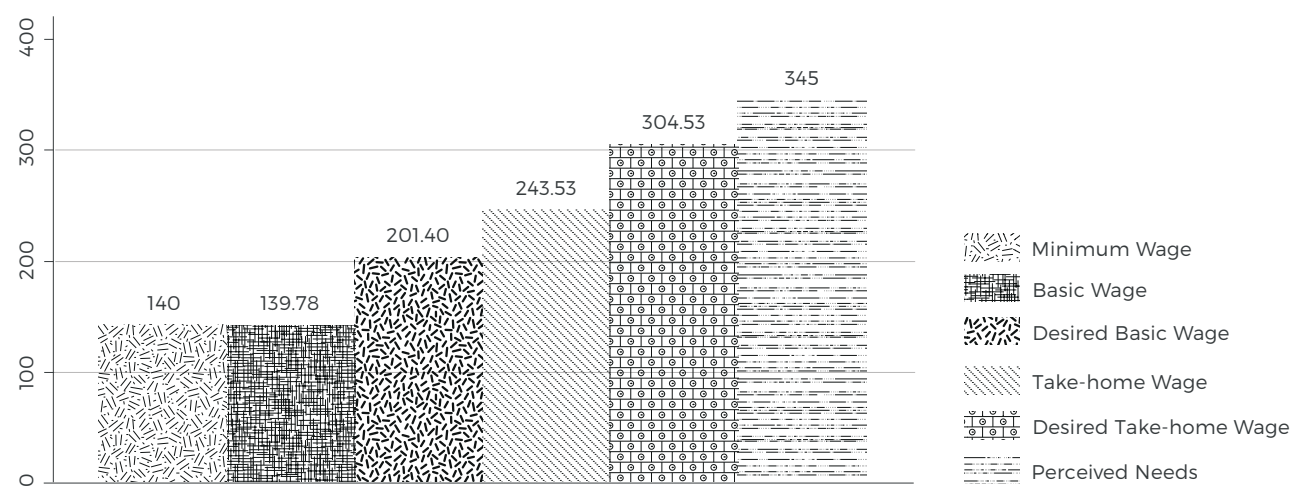

Figure 2. Wage and Perceived Needs in Cambodia, 2016 (US\$)

Source: Author's surveys.

The second column in the figures shows the basic monthly wage that the factories guarantee to workers regardless of the effective workload. What is remarkable here is that while the Cambodian factories offered a basic monthly wage that coincided with the minimum wage, in China the basic monthly wage was significantly higher ( $41.1 \%$ more) than the legal minimum. This is significant as it means that increases in the minimum wage in Cambodia have a direct impact on the income of the workers, contrarily to what happens in China, where the workers receive higher basic salaries and therefore do not have a high stake in the government's decision on the matter. Thus, it is not surprising that Cambodian workers are willing go on strike over the minimum wage, while in China the issue is shrouded in 
silence. For instance, when a labour lawyer in Shenzhen was asked what he thought about the recent decision of the Guangdong provincial authorities to freeze the minimum wage for two years in order to support companies during an economic downturn, he replied:

Honestly, it will not have the least impact [on the workers]. This thing is terribly empty, because workers generally already receive actual wages that far exceed the minimum. Strictly speaking, if you use the minimum wage to hire people on the market, you won't be able to find anybody (Interview, Shenzhen, August 9, 2016).

The third column of the figures shows the desired basic wage and is the response to the question "in a situation in which you have to work only 40 hours a week [ 48 hours in Cambodia] and do not have to work overtime, how much do you think a reasonable salary would be?" Comparing the desired basic wage with the actual basic wage highlights that workers in both countries thought it reasonable to receive significantly higher basic wages, with the Chinese workers wanting 53.1\% more and the Cambodian workers $44.1 \%$ more. The desired basic wage should also be compared with the fourth column, which shows the takehome wage; that is, how much the workers actually were paid after taxes and other deductions. While for Cambodian workers the take-home wage remained higher than the desired basic wage, this was not the case for the Chinese workers, who deemed "reasonable" to receive a basic wage even higher than what they actually were paid the previous month when doing a considerable amount of overtime. This hints at a deep dissatisfaction, a feeling that appears even more evident if we consider the fifth column, the desired take-home wage, which is the response to the question "considering your current workload, how much do you think would be a reasonable salary for you?" Chinese workers considered reasonable to receive $\mathrm{RMB} 4,374.80$ (roughly $\$ 657.24$ ) as a payment for their workload, or $34.1 \%$ more 
than their take-home wage, while Cambodian workers desired \$304.53, 25\% more than what they were making.

Still, all of this must be put in the context of the perceived economic needs, displayed in last column of the figure. As mentioned above, international advocacy groups and Cambodian independent unions have been campaigning since 2014 for a living wage of $\$ 177$ a month. A survey undertaken by several unions and NGOs in June 2016 found that workers in Phnom Penh needed around \$142 a month for their food and non-food expenditures (Centre for Policy Studies 2016). The survey question asked concerned not only basic living expenses, but was formulated in broader terms: "On average, how much do you think you need every month to cover the basic living expenses of yourself and your immediate family (your partner, children, parents or other people whom you have to support)?" This reflected the fact that, as Arnold $(2017,26)$ has noted, “workers' politics and livelihood concerns include and extend beyond the (peri-) urban factory floor to rural households." Considering that Cambodian workers came from rather extended families - besides their parents, $84.2 \%$ of them had three siblings or more - and that most family members remained in the countryside, they felt they needed an average of \$345 a month, compared to the RMB 1,958.80 (\$294.28) of the Chinese workers. Another reason why the figure is much higher in Cambodia is that while $82.4 \%$ of the Chinese workers lived in a dormitory provided by the factory - which is evidence of the persistence of the so-called "dormitory labour regime" (see Smith and Pun 2006) - paying only a symbolic fee for water, gas and electricity averaging only RMB 122 (\$18.33) a month, Cambodian workers had to find private accommodation, paying a monthly average of $\$ 34.36$. Chinese workers also had access to cheaper food, paying an average of RMB 311.57 (\$46.81) for their meals, compared to the $\$ 71.66$ paid by Cambodian workers. Finally, although this research did not touch upon this subject, many Cambodian workers and their families are also heavily indebted to microfinance institutions (Blau 2017). This 
disparity in the expenses had reverberations in the amount of remittances sent home. While Chinese workers were able to send home RMB $1,724.90$ (\$259.14) a month, or $57.5 \%$ of their take-home wage, Cambodian workers could send only $\$ 67.55$ or $22.2 \%$ of their take-home wage.

The point here is not to compare living costs and wages between the two countries in absolute terms, but rather to assess the ratio between actual wages, desired wages, and living costs, taking into account the perceptions of the workers themselves. The data collected highlight that while Chinese workers gain wages significantly higher than what they feel they need, Cambodian workers earn much less than their perceived needs. Even when asked how much they would deem "reasonable" as a compensation for their actual workload, they indicated an amount lower than what they felt necessary. This a crucial point that determines the different patterns of labour activism in the two countries: while Chinese workers are unsatisfied about their salaries because they wish to earn more in order to have more money to save or spend, Cambodian workers feel that the very subsistence of themselves and their immediate family is at risk.

\section{INSTRUMENTAL VIEWS OF THE LAW}

Wages are the most apparent reason of discontent, but there are other, more subtle factors at play in determining workers' expectations and demands. One of these factors is the saturation of the official rhetoric of labour rights promoted by the authorities through the labour law. Both China and Cambodia have adopted relatively progressive labour legislations, but the rationale that prompted the authorities in the two countries to pass such laws is very different. 
In the case of Cambodia, this was largely due to the external influence of foreign donors that in the early 1990s supported the rebuilding of the country after more than two decades of war and chaos (see Hughes 2007; Ward and Mouyly 2016). Indeed, as Slocomb $(2006,376)$ has pointed out in her study of the role of ideology in the modern Cambodian state, "hegemony is taken for granted by the Cambodian ruling elite, who have historically assumed the passive acquiescence of the masses - particularly the rural masses - and relied upon the unifying force of Khmerness, the spiritual sense of belonging to a discrete cultural group, to legitimise their use of power." In 1991, after the warring factions that were vying for power in the wake of the retreat of the Vietnamese occupying forces signed the Paris Peace Accords, the United Nations Transitional Authority in Cambodia took over the running of the country pending the democratic elections of 1993. At that time, foreign donor countries that contributed most of the government budget came to hold a disproportionate power over Cambodian politics, determining its course, language and values. Eager to gain international recognition and support, Cambodian authorities had no choice but to conform to these donor discourses, incorporating in their legislative activity and rhetoric key concepts as civil society, good governance, decentralisation, gender equality and human rights (Slocomb 2006, 391). This was reflected in the Constitution written after the signing of the peace accords, which contained commitment to the rule of law and to human rights, including specific protections of labour rights such as the right of citizens to choose their employment, equal pay for equal work, guarantee of employment for women during pregnancy, the right to maternity leave and the right to establish associations and to strike (Adler and Woolcock 2009). This kind of language - although often betrayed in practice - created spaces of opportunity for activism that eventually led to the emergence of a lively third sector of NGOs, trade unions, and community-based associations, as well as to a corresponding upsurge in political and industrial dissent. 
The appearance of the Cambodian garment industry during this early period of economic and political consolidation brought with it a stronger discourse on labour rights. As Arnold and Shih $(2010,402)$ have pointed out, the industry went through three phases of development. First, from the mid to the late 1990s, Cambodia began to establish its exportoriented garment production. Although in 1996 the authorities adopted a progressive labour law that reflected the values enshrined in the new Constitution, labour conditions remained dire. Second, from 1999 to 2004 Cambodia attempted to reinvent itself as an "ethical producer" under the US-Cambodia Textile and Trade Agreement (TATA), prompted by criticisms from international unions and anti-sweatshop movements (Polaski 2006). The agreement bound increasing import quotas to the US market with improvement in labour standards, with the International Labour Organization (ILO) in charge of monitoring progress through an innovative programme called Better Factories Cambodia (Kolben 2004). In this period, monitoring and the eagerness of the Cambodian authorities and business community to continue to benefit from TATA led to a degree of improvement in labour conditions in the garment factories, something that could be seen, for instance, in the widespread use of openended contracts (Yale Law Clinic 2011). Although the relevant literature generally portrays the Better Factories Cambodia programme as a success (DiCaprio 2013; Polaski 2006), critics have highlighted how the ILO programme, with its focus on monitoring, is the fruit of neo-liberal approach that favours social stability and economic development over the empowerment of social actors (Hughes 2007 Arnold 2017; Ward and Mouyly 2016). It was only in a third phase, after the end of TATA in 2004 and after the lifting of safeguard quotas imposed by the US government against China in 2008, that Cambodia attempted to reposition itself as a globally competitive textile and garment export platform, setting aside labour protection and focusing instead on more conventional competitive factors, such as enhancing productivity and lowering wages. Since then, while international legitimacy remains a key 
concern for the Cambodian authorities, "increasingly ... the imperative [has been] shifting to legitimation through accumulation as the state continues to depend on aid and foreign direct investment to secure its own investment, and to deflect attention from various rights concerns, including labour" (Ward and Mouyly 2016, 268-269).

In the case of China, the decision of the CCP to promote labour rights was dictated not only by the necessity to appease foreign investors, who needed a stable legal environment for their investments, but above all by the need to boost the Party's legitimacy on the internal front. According to Gallagher $(2005,101-103)$, there were three main reasons for the turn of the party-state towards the law: the need to reinforce the legitimacy of the political system, in crisis as much for the fallout of Cultural Revolution, as for the unintended consequences of the economic reforms; the necessity of having a predictable set of rules in order to open up the economy to international commerce; and the acknowledgement by the $\mathrm{CCP}$ of the importance of the "rule of law" (yifa zhiguo) as a tool of social control. Since its establishment in the early 1920s, the CCP has been presenting itself as "the vanguard of the Chinese working class" (gongren jieji de xianfengdui) - a title that to this day remains enshrined in the first article of the Party Constitution. As Chen Feng $(2007,62)$ has noted, under Maoist state socialism, Chinese workers acquired considerable social and economic entitlements, ranging from lifetime employment to substantial benefits including low-cost housing, health care, pensions, and education, but they did not enjoy real and meaningful civil and political rights.

The situation began to change only at the beginning of the reform era, as the Chinese authorities began to encourage private entrepreneurship and allowed foreign investors to set 
up shop in newly-established Special Economic Zones (SEZ). The foundations of the Chinese labour legislation were laid out in the early 1980s with the adoption of legal norms applicable exclusively in the SEZ (Sit 1985). The following decade saw the proliferation of labour regulations valid only for certain areas, sectors, or types of ownership, and in the early 1990s, the regulatory apparatus had become so chaotic that continuous uncertainties and contradictions risked becoming an obstacle for investments (Cooney, Biddulph, and Zhu 2013, 44-46). Concurrently, growing worker discontent expressed through a wave of industrial conflicts alerted the Chinese authorities to the need to find new means to boost their legitimacy among the workers (Sheehan 1998).

It was then that the CCP decided to accelerate the pace of the legislative process that eventually led to the adoption of a unified labour law, in agenda since the early 1980s but perpetually deferred pending a reform of the state industry (Josephs 1995; Yue 2011; Cooney, Biddulph, and Zhu 2013, 50-52). In July 1994, after a series of consultations between the Ministry of Labour, the official union and the academic community, they passed the first Labour Law of the People's Republic of China (Yue 2011). In its final formulation, the text of the Law remained very vague, leaving a free hand for the party-state to intervene in industrial relations (Harper Ho 2009, 37). Besides maintaining several grey areas - in particular for what concerned atypical forms of labour - the new legislation also included many exceptions aimed at not scaring investors away (Cooney, Biddulph, and Zhu 2013; Xu 2008-2009). Even more important, the Labour Law introduced a strong imbalance between the protection of individual rights, described in very detailed terms, and collective rights, which the party-state considered politically threatening and therefore chose to water down or ignore altogether (Chen 2007, 60). Although in the 2000s the Chinese authorities further codified labour legislation with the adoption of a series of fundamental laws - some of which had attracted strong opposition by both domestic and foreign business groups due to their perceived 
partisanship towards the interests of labour (Gallagher and Dong 2011) - this imbalance between individual and collect rights was never redressed.

In sum, while in Cambodia, the official discourse of labour rights is mainly targeted at foreign donors, the Chinese authorities have promoted labour rights in order to boost internal legitimacy and maintain social stability. In particular, the Chinese authorities have realised that the law can be a powerful instrument to circumscribe the demands of the workers within politically acceptable discursive boundaries - for instance, allowing individual economic demands and discouraging collective political ones - thus preventing labour discontent from escalating into a political challenge (Chan and Siu 2011; Cheng 2017; Hui 2016a; 2016b). In this respect, Chinese labour law can be considered as an hegemonic discourse (Blecher 2002), or, in Hui's words, as an “ endeavour of the ruling class to constitute workers' worldviews and values in such ways that the latter may criticize, but not challenge fundamentally, the legitimacy of the capitalist economy and the party-state, and that they may resist, but not take rebellious actions to transform the socio-political and economic systems" (Hui 2017, 81).

In practice, do these different instrumental views of labour rights have an impact on how garment workers perceive their entitlements in China and Cambodia? The survey results reported here suggest that this is the case in at least three respects. First, while legal awareness is generally low in both countries, with most Cambodian workers requiring long explanations about the meaning of "labour law," Chinese workers displayed a selective knowledge of labour rights that is very much in line with the official discourse in its focus on individual rights, especially those related to workers' direct economic interests. For instance, more than $81 \%$ of the Chinese workers were able to reply correctly to a series of questions on how to calculate the overtime payment on ordinary days, weekends and public holidays, while less than $10 \%$ of the Cambodian workers were able to reply to the same question regarding overtime payment on ordinary days, a figure that shot up to around $65 \%$ for overtime on 
Sundays and public holidays. The opposite was true for those norms that do not impact economic interests, for instance those on the legal limits to the amount of overtime, which, if enforced, would significantly reduce the income of the workers. Only $1.2 \%$ of the Chinese workers knew that their overtime should not have exceeded 36 hours a month, compared to $90.7 \%$ of the Cambodian workers who knew that their overtime should not have exceeded two hours a day.

Second, there are marked differences between the workers in the two samples in the level of confidence in the law, with the Chinese workers much more ready to have faith until proved otherwise - in the power of the legal system to protect them, a finding in line with the Gallagher and Wang $(2013,204)$ observation that in China "legal experience leads to higher levels of disillusionment and more negative perceptions of the legal system's effectiveness and fairness... non-users tend to have vague but benevolent notions of the legal system and its effectiveness." When asked whether they believed that the national labour law was able to protect the rights of the workers, $85.9 \%$ of the Chinese workers responded affirmatively, compared to $57.7 \%$ of the Cambodian workers. This trust in the law in the Chinese case clearly does not come from direct experience, as only $0.4 \%$ of the Chinese sample - one person - had attempted to solve a problem through the legal system and only 14\% knew somebody who had, while in Cambodia the respective percentages were $15.5 \%$ and $52.2 \%$. Nor does this faith automatically translate into willingness to demand redress for rights violations through the legal system, often perceived in both countries as a timeconsuming, expensive, and complicated option. In particular, as we will see, in China it remains easier for the workers to "vote with their feet" than to undertake a long and possibly costly legal fight, especially in light of the availability of jobs due to the labour shortages in coastal areas.

Finally, there are significant discrepancies in the perception of the state's role in the 
event of a labour dispute. The Chinese legislation provides a process for the resolution of labour disputes articulated in four stages: (i) mediation, which is supposed to be voluntary, but in many cases becomes mandatory, as the authorities attempt to reduce the burden on arbitration committees and courts; (ii) arbitration by arbitral committees set up by local labour departments, which are bound to give an award in no more than 60 days, with the arbitral award considered binding in disputes on matters related to the payment of wages, the reimbursement of medical expenses for labour-related injuries, and compensations of an amount lower than 12 months of minimum wage; (iii) and two levels of judgement in court (Harper Ho 2009). In Cambodia, instead, labour disputes are supposed to be resolved through workplace-level negotiations, conciliation by the Labour Inspectorate of the Ministry of Labour and Vocational Training, the courts, or by arbitration by the Arbitration Council a national tripartite body (Ponak and Taras 2016). Conciliation is voluntary in individual cases, but mandatory in collective disputes. If conciliation fails, either party can bring the case to court, but in the event of a collective dispute first they are obliged to go through arbitration, which should take no more than 15 days of referral. In such a context, my survey shows that Chinese workers are more prone to seek help from bureaucratic actors close to the party-state instead of resorting to independent or semi-independent actors, such as labour NGOs, law firms and media, a finding that resonates with Landry's conclusion that Chinese citizens are more trusting of those institutions that are closely associated with the state than with nonbureaucratic actors (Landry 2009).

When asked what they would have done in the event of a problem with their managers, only $21.6 \%$ of the Chinese workers said that they would have been willing to stand up to "protect their rights," $6.8 \%$ stated that they would have "endured it," and 71.6\% declared that they would have simply "changed to a better job" - a situation that can be explained in relation to the relative easiness with which workers can switch to a different job 
in the current market circumstances. In Cambodia, where workers face a fundamental challenge to their survival and cannot afford to lose a job for long periods of time, it was exactly the opposite: $74.9 \%$ of the workers were willing to stand up for their rights, compared to $13.7 \%$ who would have endured it and $11.3 \%$ who would have walked away. More importantly, those who replied that they were willing to fight for their rights were asked who they would have sought help from at first. In China, $74 \%$ of the respondents declared that they would seek help from labour departments, the lowest echelon of the labour bureaucracy, plus an additional $7.4 \%$ who expressed their preference for the local office for letters and visit, an extra-judicial state body in charge of receiving petitions from citizens. In other words, most Chinese workers would have sought the help of the party-state in solving a dispute, a further display of trust towards officialdom. In Cambodia, on the contrary, as much as $88.5 \%$ of the respondents declared that they would seek help from a trade union, that, is, a body outside the state (although many Cambodian unions remain little more than "yellow" unions).

The fact that the Chinese workers sampled maintained a highly individualistic view of labour rights, believed in the power of the law promulgated by the authorities to protect them, and were ready to seek help from the party-state when in need supports the claim that the Chinese labour law functions as a "hegemonic discourse" that shores up labour activism. Of course, as noted above, most of those workers did not have any experience with the law. If they had, they probably would have found out about the many limitations of the legal system and the inability or unwillingness of the party-state to provide help, which, in turn, would have made them disenchanted and possibly more prone to engage in activism. Indeed, as Gallagher has noted, Chinese workers who had experienced the complicated end result of a labour dispute developed an attitude of "informed disenchantment," which contains "elements of raised legal consciousness in terms of knowledge about the law and feelings of greater 
efficiency and understanding of legal strategy with a concomitant sense of disappointment and frustration about inequities and dysfunctional aspects of China's developing legal system" (Gallagher 2006, 281-282). Yet, not that many workers in China ever find themselves in a situation in which they have to put their faith to test, which means that the official discourse holds up among large swathes of the workforce. In Cambodia, on the contrary, there is no faith in the thaumaturgical power of the state, and workers are more prone to take matters in their own hands. That Cambodian garment workers refer to the unions as their favourite choice when seeking redress in the event of a labour dispute also highlights a fundamental difference in the perception of labour rights among Cambodian and Chinese workforce: while Chinese worker are largely unaware of collective rights, which are ignored or watered down in the existing legislation and official discourse, in particular on matters related to trade unions and freedom of association, as will be detailed in the next section, their Cambodian counterparts are highly cognisant of what a union is and how it is supposed to work.

\section{UNION PLURALISM AND PERCEPTION OF STRIKES}

To this day, the ACFTU maintains a monopoly of labour representation in China. The ACFTU is a mass organisation of Leninist imprint that is supposed to function as a "transmission belt" between the CCP and the workers, as well as a dispenser of social welfare and assistance. Counting almost 300 million members, the ACFTU considers any attempt at labour organising outside its hierarchy as a fundamental threat to its legitimacy and it goes to considerable lengths to crush labour NGOs and other forms of spontaneous worker solidarity (Bloomberg, November 11, 2016). ${ }^{4}$

In Cambodia the situation is different. During the Vietnamese occupation, the 
authorities set up a system of union-like "syndicates" embedded in government ministries or agencies in provinces and districts (Nuon and Serrano 2010, 20). Since the mid-1990s, with the growth of the garment industry and especially after the enforcement of TATA, union federations started to appear. Some were politically aligned with the ruling party and pushed the view that unions could assist workers in achieving their rights without resorting to strikes, but using negotiations and patronage instead; others sided with the opposition and adopted a more militant approach in which labour struggles were linked to broader political goals; and others again considered themselves "independent," flaunting strong links to international NGOs and civil society (Nuon and Serrano 2010, 25-27). The existence of a political opposition to the regime led by Hun Sen's Cambodian People's Party (CPP) - embodied in the 1990s by the Sam Rainsy Party (previously known as Khmer Nation Party) - played a particularly important role in fostering trade unionism in Cambodia (Norén-Nilsson 2016, 141). While paying lip service to civil society and labour rights to appease foreign donors, the Cambodian authorities were wary of the political threat posed by those non-aligned unions and, in order to weaken them, encouraged the establishment of union federations in line with their interest and priorities. Concomitantly, they also resorted to more extreme measures, condoning - if not encouraging - violence when it helped to keep the most outspoken unions in check. In January 2004, Chea Vichea, president of the main opposition-aligned union federation, the Free Trade Union of Workers of the Kingdom of Cambodia was gunned down in broad daylight in the centre of Phnom Penh, in a political killing that sent shock waves throughout the nascent Cambodian labour movement. Another unionist from the same federation was killed later the same year and yet another in 2007 (Nuon and Serrano 2010, 26-27).

While shocking, these deaths did not stop independent and oppositional unionism, which could count on the steadfast support first of the Sam Rainsy Party and then, from 2012, 
of the newly-formed Cambodian National Rescue Party, which in recent years - before being disbanded in November 2017 - has consistently been campaigning for higher minimum wages, framing this as a right (Norén-Nilsson 2016, 185). Based on data provided by the Cambodian Labour Confederation (April 2, 2015), in 2014, there were 13 union confederations (only four of which appeared to be active), 79 federations and 2,981 plant unions. The unionisation rate in the garment sector is particularly high, with about $60 \%$ of Cambodian garment workers holding union membership. Still, as Arnold and Shih (2010, 416) have pointed out, such a high rate does not mean that Cambodian unions are necessarily strong, as such fragmentation leaves "many unions weak, under-funded, competing with one another, and subject to corruption and political interference by the CPP.” Arnold (2017, 28) has also questioned "the potential for hierarchically organized, workplace-oriented unions, typically male-led in a feminized sector, to represent adequately the complex multiplicity of class subjects, experiences and desires," a situation that in recent years has often led workers bypassing the unions and mobilising spontaneously to put forward their demands. The future of the Cambodian independent unions is further threatened by the ruling party's increasingly authoritarian rule, in particular by the passage in April 2016 of a very controversial Trade Union Law that established a series of strict requirement for the process of union formation, imposed burdensome reporting obligations and severely limits the right to strike (Palatino 2016).

This article highlights a significant difference in how garment workers in China and Cambodia relate to the unions. Although all Chinese factories in the survey had a branch of the ACFTU on their premises, the workers were largely unaware of this. Not only did $70.3 \%$ of the Chinese workers not know whether there was a union in their factory $-56 \%$ had no clue even whether they were union members - but also, when asked if they knew what a trade union was, $50 \%$ of them stated that it was "not clear," to them, with an additional $28 \%$ saying 
that they had never heard the word "trade union" (gonghui) before. None of the workers who declared that their factory had a union had ever taken part in a union election, nor believed the factory union could represent the interests of the workers. This lack of knowledge among workers with a relatively long employment history may appear surprising if we consider that the term "trade union" is current in the Chinese public debate, but it can be explained in light of three factors. First, Chinese garment workers are mostly low-skilled migrants who have spent their working life in private manufacturing companies, a context in which unions play almost no role, compared, for instance, to state-owned companies or other government-run institutions, where unions at least provide some welfare and organise some recreational activities. Second, grassroots unions in private companies are for the most part set up by the employers to comply with top-down demands and feature managers in top positions, with the result that they are completely detached from the actual workforce. Finally, as we have seen, the trade union that features in the official propaganda of the party-state is little more than a top-down dispenser of social welfare. This detachment emerged clearly from the interviews. When Chinese garment workers were asked their opinion about what the proper function of a union should be, the most common answer - after "I don't know" - was that unions should “organise recreational activities," such as basketball games, birthday parties and outings, or distribute small gifts to the workers, a response that mirrored the official discourse of the Chinese authorities on the role of the trade unions. Only one worker mentioned that the union should take care of the wages of the workers (Interview, Dongguan, September 11, 2016).

In Cambodia, on the contrary, despite all the constraints that mar the activities of trade unions, garment workers had a much clearer picture of the associational life in their factories, where multiple unions were competing for membership. Fully $96.9 \%$ knew for certain that there were unions in the factory, $78.7 \%$ declared that they were union members, and $63.6 \%$ claimed to know what a trade union is (with a further $6.9 \%$ claiming to "know a little"). Even 
if only $22.3 \%$ of the Cambodian workers had taken part in the election of union representatives - which hints at a lack of union democracy $-84.4 \%$ believed that the factory unions were able to represent the interests of the workers. Moreover, unlike their Chinese counterparts, the Cambodian workers who were interviewed had a very clear idea of how a union should work. While some of them complained about the corruption of union officials and expressed discontent about the continuous infighting among unions, the refrain in conversations was that the union should "look after the workers, understanding their problems and their needs" (Interview, Phnom Penh, September 15, 2016), that unions "help to solve problems for the workers, for instance by negotiating on their behalf in the event of a dispute with the factory" and they will "not allow the employers to get their way with the workers" (Interviews, Phnom Penh, September 13, 2016).

What about the workers' perception of fundamental collective rights, such as the right to bargain collectively and the right to strike? In both countries, knowledge of collective bargaining was low: as many as $87.6 \%$ of the Cambodian workers did not know what collective bargaining is, compared to $98.8 \%$ of the Chinese workers. This can be explained considering that this issue remains quite marginal in the Cambodian political debate, while the Chinese official discourse defines collective bargaining (jiti tanpan) as "collective negotiation" (jiti xieshang), a largely formalistic and non-confrontational process led by the official union and of scarce consequence for the workers (Chan and Hui 2014, 225). For what concerns the right to strike, my findings are more ambiguous. Although China has ratified the International Covenant on Economic, Social, and Cultural Rights, which at article 8.1(d) binds the government to ensure "the right to strike, provided that it is exercised in conformity with the laws of the particular country," the legislation does not mention the right to strike, consigning it to a grey area (Chang and Cooke 2015, 441). In Cambodia, instead, the Labour Law allows workers to strike, but only after all other methods of dispute resolution - 
negotiation, conciliation, and arbitration - have failed and after the union members have approved the strike by secret ballot and given a seven working days' notice to both employer and Ministry of Labour. Given these onerous restrictions, even in Cambodia labour stoppages have always been - and will likely continue to be - mostly spontaneous and formally illegal. Considering these different legal contexts, how do Chinese and Cambodian workers perceive strikes as strategy to protect their rights? According to survey responses, Cambodian garment workers are much more prone to see strikes in a positive light. While only $3.2 \%$ of the Chinese workers in the sample admitted that they had joined a strike before, $55.5 \%$ of their Cambodian counterparts did. More important, when asked whether they agreed with people or organisations resorting to strikes to protect their rights and interests, only $38.4 \%$ of the Chinese workers said that they "totally agreed" (3.6\%) or "quite agreed" (34.8\%), compared to $66.5 \%$ of the Cambodian workers (23.2\% of whom "totally agreed").

These data highlight a substantial difference in the way Chinese and Cambodian garment workers relate to trade unions. Chinese workers are largely unaware of the existence of unions in their workplace and generally believe that such organisation should do little more than organise recreational activities. This attitude has clearly been fostered by the Chinese party-state - as well as by the ACFTU - not only through laws and regulations that reinforce the monopoly of the official union and restrict its role to welfare provision, but also through sheer repression of autonomous labour organising in any form (Franceschini and Nesossi 2018). In this context, Chinese workers are reduced to individuals and their collective power is shattered, unless some traumatic event such as the closure of the factory, the discovery that social security contributions have not been paid, or mass lay-offs - brings them together in a common struggle. Even in that case, though, adopting extreme measures such as going on strike remains a last resort for them, a desperate measure to deal with a hopeless situation. In Cambodia, the situation is very different. Although the existing legislation seriously hinders 
the ability of trade unions in Cambodia to launch strikes and most labour mobilisations in the country thus remain formally illegal, unions play a fundamental role in fostering worker solidarity. At the national level, they do so by constantly campaigning for better labour conditions and higher minimum wages, by carrying out surveys and investigations and by assisting workers in their individual and collective struggles. At the grassroots level, the need to compete in order to boost their membership push Cambodian grassroots unionists to follow up on workers' problems, taking leadership roles in the event of a dispute and even encouraging workers to go on strike. Most important, the very existence of independent unions in the country reminds the workers even in those factories that are not unionised that collective struggle - although not devoid of risks - is always a possibility. This fundamental difference has momentous consequence for the patterns of activism of Chinese and Cambodian workers in the garment sector and beyond.

\section{CONCLUSION}

The Cambodian and Chinese garment industries are both characterised by considerable precariousness and exploitation and in both countries workers who engage in workplace activism face dire consequences. Why then are Cambodian garment workers more prone to undertake large-scale co-ordinated industrial actions to demand higher wages than their Chinese counterparts? To respond to this question, this article has compared Cambodian and Chinese garment workers in three main respects: their expectations towards wages; their awareness and perception of the labour law; and their relationship with the unions.

Concerning wages, workers in the two countries are substantially unsatisfied with the level of their remuneration and believe that they should earn more in light of their workload. 
Still, while Chinese workers live in dormitories provided by the factory and generally come from relatively small families with more than one breadwinner - a result of the one-child policy and of four decades of economic reforms - Cambodian workers usually have to rent their own accommodation outside the factory and need to support large families who stay behind in the rural areas. This determines a significant gap in the living expenses, remittances, and perceived needs of the two workforces, with Chinese workers gaining wages significantly higher than what they feel they need and their Cambodian counterparts earning much less than their perceived needs. In other words, while Chinese garment workers are unsatisfied because of what they think is an "unreasonable" remuneration for their labour, Cambodian garment workers feel that the very survival of their family is at risk.

Regarding workers' awareness and perception of the labour law, it is apparent that the Chinese and Cambodian authorities have adopted progressive labour legislations for very different reasons. While the Cambodian government sought to use the language of labour rights in order to boost its standing among foreign donors, the rhetoric of the Chinese partystate represents an effort to boost its internal legitimacy, as well as an attempt to circumscribe the demands of the workers within politically acceptable discursive boundaries. This effort to promote the labour law as a "hegemonic discourse" in China seems to have borne its fruits, as Chinese garment workers, compared to their Cambodian counterparts, display a higher awareness - although still low in general terms - of those individual rights that have a direct impact on their income, and an almost non-existent awareness of collective rights. Moreover, Chinese garment workers display considerable trust in the ability of the party-state and its bureaucracy to protect their rights and interests, although in most cases this faith is based on a lack of experience, as very few ever have a chance test the official channels to solve a labour dispute, as quitting and finding a new job remains far easier. While this penetration of the official discourse of labour rights can be seen as constituting a brake on the activism of 
Chinese garment workers, this is not the case in Cambodia, where workers are largely unaware even of the existence of the labour legislation and are not constrained by a belief in the power and willingness of the authorities to help them.

On the matter of the trade unions, contrary to what happens in China, where union monopoly belongs to a single official organisation, in Cambodian garment factories there is a plurality of unions vying for the support of workers. Although Cambodian unions work in a highly repressive environment and face significant legal limitations that curb their effectiveness in protecting members' rights and interests, this disparity has practical implications for labour activism. Chinese garment workers generally do not know whether there is a union in their factory, nor do they have any clear idea about what a union is and how it is supposed to work. On the contrary, most Cambodian garment workers are union members and - although few have ever taken part in a union election - they believe that factory unions can stand up for their rights. Unsurprisingly, in the event of a labour dispute, most Cambodian workers would seek help from the unions; this would be almost unthinkable for their Chinese counterparts. All of this confirms that Chinese garment workers have a low awareness of collective rights, a finding that can be seen also in the data that show that Cambodian workers are much more approving of strikes as a way to protect their rights than their Chinese counterparts. In other words, union pluralism, albeit flawed, plays a fundamental role in boosting workers' solidarity and collective struggles.

The elements analysed in this article obviously do not exhaust all the possible factors that foster and shape labour activism in contexts as complex and diverse as contemporary China and Cambodia. Still, by comparing the two contexts and peering into the subjectivity of workers in different countries - their expectations, legal knowledge and even feelings - it is possible to gain some new insights not only on how states attempt to control and channel labour activism, but also on why workers react in different ways to the common challenges 
they face. Only by this act of intellectual voyeurism will we be able to understand - and possibly overcome - the limitations of much labour activism today. 


\section{FUNDING DETAILS}

This work was supported by the European Union Horizon 2020 Research and Innovation Programme under the Marie Skłodowska-Curie grant agreement No. 654852.

\section{ACKNOWLEDGMENTS}

The author would like to thank Professor Anita Chan, Dr Nicholas Loubere, and Dr Christian Sorace for their valuable comments on earlier versions of this paper; Ratana Heng, Lucy Wang, and William Conklin for their help in arranging fieldwork; and Nan Liu for her assistance with the analysis of data. He also wishes to acknowledge the participants to the 2017 Made in China Summer School for their feedback. 


\section{REFERENCES}

Adler, D., and M. Woolcock. 2009. Justice Without the Rule of Law? The Challenge of Rights-based Industrial Relations in Contemporary Cambodia. Washington DC: World Bank Justice and Development Working Paper Series 2 (2).

Arnold, D. 2014. "Workers' Agency on Power Relations in Cambodia's Garment Industry."

In Towards Better Work: Understanding Labour in Apparel Global Value Chains, edited by A. Rossi, A, Luinstra, and J. Pickles, 212-231. Basingstoke: Palgrave Macmillan.

Arnold, D. 2017. "Civil Society, Political Society and Politics of Disorder in Cambodia." Political Geography 60: 23-33.

Arnold, D., and H.-S. Toh. 2010. “A Fair Model of Globalisation? Labour and Global Production in Cambodia." Journal of Contemporary Asia 40 (3): 401-424.

AMRC. 2014. A Week That Shook Cambodia: The Hope, Anger, and Despair of Cambodian Workers After the General Strike and Violent Crackdown. Hong Kong: Asia Monitor Resource Centre.

Blau, G. 2017. "Chumpea Loy: Debt and the Making of the Khmer Working Class.” Unpublished Masters dissertation, University of Amsterdam. 
Blecher, M. 2002. "Hegemony and Workers' Politics in China.” The China Quarterly 170: 283-303.

Centre for Policy Studies. 2016. "Survey on Expenditures of Workers in Garment and Footwear Sector in Cambodia." Centre for Policy Studies in collaboration with IndustriALL, ACILS and FES. Presented at the Sunway Hotel, Phnom Penh, July 30.

Chan, A. 2015. “Trade Union Elections at Foreign-owned Chinese Factories.” China: An International Journal 15 (3): 94-113.

Chan, A. 2016. Chinese Workers in Comparative Perspective. Ithaca: Cornell University Press.

Chan, A., and K. Siu. 2010 “Analyzing Exploitation: The Mechanisms Underpinning Low Wages and Excessive Overtime in Chinese Export Factories." Critical Asian Studies 42 (2): $167-90$

Chan, A., and K. Siu. 2011. "Made in China: Work and Wages in Walmart Supplier Factories." In Walmart in China, edited by A. Chan, 71-94. Ithaca: Cornell University Press.

Chan, A., and K. Siu. 2012. "Chinese Migrant Workers: Factors Constraining the Emergence of Class Consciousness." In China's Peasants and Workers: Changing Class Identities, edited by B. Carrillo and D. Goodman, 79-101. London: Edward Elgar. 
Chan, C. 2010. The Challenge of Labour in China: Strikes and Changing Labour Regime in Global Factories, London: Routledge.

Chan, C., and E. Hui. 2012. "The Dynamics and Dilemma of Trade Union Reform in China: The Case of the Honda Workers' Strike.” Journal of Industrial Relations 54 (5): 653-668.

Chan, C., and E. Hui. 2013. "The Development of Collective Bargaining in China: From 'Collective Bargaining by Riot' to 'Party State-Led Wage Bargaining'." The China Quarterly 217: $221-242$.

Chan, C., and N. Pun. 2009. "The Making of a New Working Class? A Study of the Collective Actions of Migrant Workers in South China." The China Quarterly 198: 287-303.

Chang, K., and F.-L. Cooke. 2015. "Legislating the Right to Strike in China: Historical Development and Prospects.” Journal of Industrial Relations 57 (3): 440-455.

Chen, F. 2007. "Individual Rights and Collective Rights: Labor's Predicament in China.” Communist and Post-Communist Studies 40: 59-79.

Cheng, X. 2017. "From Political Enchantment to Legal Logic - A Discursive Analysis of Contentious Labor Politics in Central China.” Journal of Contemporary China 26 (106): 549563. 
Chiu, C. 2007. "Workplace Practices in Hong Kong-invested Garment Factories in Cambodia.” Journal of Contemporary Asia 37 (4): 431-448.

Clean Clothes Campaign. 2015. "Global Living Wage Campaign for Cambodia Kicks Off." Clean Clothes Campaign, November 20. Accessed December 8, 2017. https://cleanclothes.org/news/2015/11/20/global-living-wage-campaign-for-cambodia-kicksoff.

Cooney, S., S. Biddulph, and Y. Zhu. 2013. Law and Fair Work in China. New York, Routledge.

Derks, A. 2008. Khmer Women on the Move: Exploring Work and Life in Urban Cambodia. Honolulu: University of Hawai'i Press.

DiCaprio, A. 2013. “The Demand Side of Social Protection: Lessons from Cambodia's Labor Rights Experience.” World Development 48: 108-119.

Fan, L. 2016. "The Self-Organization of Women Workers in the Informal Sector of the Garment Industry: A Study of Female-Led Cooperative Production Teams in the Yangtze River Delta Region of China.” In China at Work: A Labour Process Perspective on the Transformation of Work and Employment in China, edited by M. Liu and C. Smith, 123-149. New York: Palgrave Macmillan. 
Franceschini, I., and E. Nesossi. 2018. "State Repression of Chinese Labour NGOs: A Chilling Effect?” The China Journal 80: 111-129.

Franceschini, I., K. Siu, and A. Chan. 2016. "The 'Rights Awakening' of Chinese Migrant Workers: Beyond the Generational Perspective." Critical Asian Studies 48 (3): 422-442.

Friedman, E. 2014. The Insurgency Trap: Labor Politics in Postsocialist China. Ithaca: Cornell University Press.

Gallagher, M. 2005. Contagious Capitalism: Globalization and the Politics of Labour in China. Princeton, Princeton University Press.

Gallagher, M. 2006. 'Mobilizing the Law in China: 'Informed Disenchantment' and the Development of Legal Consciousness.” Law and Society Review 40 (4): 783-816.

Gallagher, M. 2007. “'Hope for Protection and Hopeless Choices': Labor Legal Aid in the PRC.” In Grassroots Political Reform in Contemporary China, edited by E. Perry and M. Goldman, 196-227. Cambridge: Harvard University Press.

Gallagher, M., and B. Dong. 2011. "Legislating Harmony: Labor Law Reform in Contemporary China." In From Iron Rice Bowl to Informalization: Market, Workers and the State in a Changing China, edited by S. Kuruvilla, C.-K. Lee, and M. Gallagher, 36-60. 
Ithaca, Cornell: University Press.

Gallagher, M., and Y. Wang. 2013. "Users and Non-Users: Legal Experience and Its Effect on Legal Consciousness." In Chinese Justice: Civil Dispute Resolution in Contemporary China, edited by M. Woo and M. Gallagher, 204-233. New York: Cambridge University Press.

Gallagher, M., and Y. Yang. 2017. "Getting Schooled: Legal Mobilization as an Educative Process.” Law \& Social Inquiry 42 (1): 163-194.

Harper Ho, V. 2009. "From Contracts to Compliance? An Early Look at Implementation under China's New Labor Legislation.” Columbia Journal of Asian Law 23 (1): 33-107

Hong Kong Trade Development Council. 2017. "Economic and Trade Information on Hong Kong.” Hong Kong: HKTDC Research. Accessed September 19, 2017. http://hong-kongeconomy-research.hktdc.com/business-news/article/Market-Environment/Economic-andTrade-Information-on-Hong-Kong/etihk/en/1/1X000000/1X09OVUL.htm.

Hughes, C. 2007. “Transnational Networks, International Organizations and Political Participation in Cambodia: Human Rights, Labour Rights and Common Rights.” Democratization 14 (5): 834-852. 
Hui, E. 2016a. "Putting the Chinese State in its Place: A March from Passive Revolution to Hegemony." Journal of Contemporary Asia 47 (1): 66-92.

Hui, E. 2016b. "The Labour Law System, Capitalist Hegemony and Class Politics in China." The China Quarterly 226: 431-455.

Hui, E. 2017. “The Neglected Side of the Coin: Legal Hegemony, Class Consciousness, and Labour Politics in China." In Made in China Yearbook 2016: Disturbances in Heaven, edited by I. Franceschini, K. Lin, and N. Loubere, 80-83. Canberra: ANU Press.

ILO. 2017. Cambodian Garment and Footwear Sector Bulletin 5. International Labour Organisation. Accessed December 8, 2017. http:/www.ilo.org/wcmsp5/groups/public/--asia/---ro-bangkok/documents/publication/wcms_541288.pdf.

Josephs, H. 1995. "Labor Law in a 'Socialist Market Economy': The Case of China." Columbia Journal of Transnational Law 33: 559-579.

Kolben, K. 2004. “Trade, Monitoring, and the ILO: Working to Improve Conditions in Cambodia's Garment Factories.” Yale Human Rights \& Development Law Journal 7: 79-120.

Landry, P. 2009. “The Diffusion of Legal Institutions in China.” In Socialist China, Capitalist China, edited by G. Wu and H. Lansdowne, 138-168. London: Routledge. 
Lee, C.-K. 2007. Against the Law: Labor Protests in China Rustbelt and Sunbelt, Berkeley: University of California Press.

Lee, C.-K. 2016. "Precarization or Empowerment? Reflections on Recent Labor Unrest in China." The Journal of Asian Studies 75 (2): 317-333.

Levitsky, S., and L. Way. 2010. Competitive Authoritarianism: Hybrid Regimes After the Cold War. New York: Cambridge University Press.

Liu, M., C. Li, and S. Kim. 2011. "Chinese Unions in Transition: A Three-Level Analysis.” In China's Changing Workplace, edited by P. Sheldon, S. Kim, Y. Li, and M. Warner, 277300. London: Routledge.

McCargo, D. 2005. “Cambodia: Getting Away with Authoritarianism?” Journal of Democracy 16 (4): 98-112.

Norén-Nilsson, A. 2016. Cambodia's Second Kingdom: Nation, Imagination, and Democracy. Ithaca: Cornell Southeast Asia Program Publication.

Nuon, V., and M. Serrano. 2010. Building Unions in Cambodia: History, Challenges, Strategies. Singapore: Friedrich-Ebert-Stiftung. 
Palatino, M. 2016. "The Trouble with Cambodia New Law on Trade Unions." The Diplomat, April 18. Accessed December 8, 2017. http://thediplomat.com/2016/04/the-trouble-withcambodias-new-law-on-trade-unions.

Polaski, S. 2006. "Combining Global and Local Forces: The Case of Labour Rights in Cambodia." World Development 34 (5): 919-932.

Ponak, A., and D. Taras. 2016. "Rule of Law and the Arbitration Council of Cambodia." Employee Rights and Employment Policy Journal 20 (1): 37-69.

Schmalz, S., B. Sommer, and H. Xu. 2017. "The Yue Yuen Strike: Industrial Transformation and Labour Unrest in the Pearl River Delta.” Globalizations 14 (2): 285-297.

Sheehan, J. Chinese Workers: A New History. London: Routledge.

Sit, V.1985. "The Special Economic Zones of China: A New Type of Export Processing Zone?" The Developing Economies 23 (1): 69-87.

Siu, K. 2017. "Labor and Domination: Worker Control in a Chinese Factory." Politics \& Society 45 (4): 533-557. 
Slocomb, M. 2006. "The Nature and Role of Ideology in the Modern Cambodian State." Journal of Southeast Asian Studies 37 (3): 375-395.

Smith, C., and N. Pun. 2006. "The Dormitory Labour Regime in China as a Site for Control and Resistance." The International Journal of Human Resources Management 17 (8): 14561470.

Taylor, B., and Q. Li. 2007. "Is the ACFTU a Union and Does It Matter?” Journal of Industrial Relations 49 (5): 701-715.

Van Der Kamp, J. 2016. “Why Textile Trade Is Slipping Through China’s Fingers.” South China Morning Post, January 20. Accessed December 8, 2017. http://www.scmp.com/business/global-economy/article/1903487/why-textile-trade-slippingthrough-chinas-fingers.

Ward, K., and V. Mouyly. 2016. "Employment Relations and Political Transition in Cambodia.” Journal of Industrial Relations 58 (2): 258-272.

WITS. 2018a. "China Textiles and Clothing Exports By Country and Region 2016.” World Integrated Trade Solution Database. Accessed November 29, 2018. https://wits.worldbank.org/CountryProfile/en/Country/CHN/Year/2016/TradeFlow/Export/Pa rtner/all/Product/50-63_TextCloth. 
WITS. 2018b. "Cambodia Textiles and Clothing Exports By Country and Region 2016." World Integrated Trade Solution Database. Accessed November 29, 2018. https://wits.worldbank.org/CountryProfile/en/Country/KHM/Year/2016/TradeFlow/Export/Pa rtner/all/Product/50-63_TextCloth.

Wong, L. 2011. “Chinese Migrant Workers: Rights Attainment Deficits, Rights Consciousness and Personal Strategies.” The China Quarterly 208: 870-892.

WRC. 2014. Crackdown in Cambodia: Workers Seeking Higher Wages Meet Violent Repression. Washington, D.C.: Worker Rights Consortium.

$\mathrm{Xu}, \mathrm{F}$. "The Emergence of Temporary Staffing Agencies in China." Comparative Labour Law and Policy Journal 30: 431-462.

Yale Law School. 2011. Tearing Apart at the Seams: How Widespread Use of Fixed Duration Contracts Threatens Cambodian Workers and the Cambodian Garment Industry. Accessed November 27, 2018.

https://www.law.yale.edu/system/files/documents/pdf/Intellectual_Life/Cambodia_TearingAp artattheSeams.pdf.

Yang R. 2015. "Political Process and Widespread Protests in China: The 2010 Labor Protest." Journal of Contemporary China 24 (91): 21-42. 
Yue, J. 2011. “'Laodongfa' de zhiding guocheng: Jiyu duo yuanliu moshi de fenxi” [The Drafting Process of the Labour Law: An Analysis Based on Multiple Models]. In Zhongguo Laodongzhe Weiquan Wenti Yanjiu, edited by M. Zhao, W. Zhao, and L. Fan, 15-57. Beijing: Shehui Kexue Wenzhai Chubanshe.

Zhang, L. 2015. Inside China's Automobile Factories: The Politics of Labor and Worker Resistance. New York: Cambridge University Press.

Zhang, Y., and Y. Liu. 2012. 'Laodongli shichang de bianhua ji 'zhaogongnan' wenti diaoyan baogao" [Report on the Situation of the Labour Market and the Outbreak of the "Recruitment Crisis"]. In 2012 nian zhongguo shehui xingshi fenxi yu yuce, edited by X. Ru, X. Lu, and P. Li, 145-161. Beijing: Shehui Kexue Wenzhai Chubanshe). 


\section{NOTES}

${ }^{1}$ The exchange rate was set at around 4,000 riel per dollar. In this article, all costs in Cambodia are in US\$, which is the currency to which workers and people generally referred to in their daily life and in interviews and discussions.

${ }^{2}$ There have been some notable exceptions. See Chan (2010), Chan and Hui (2012), Chan and Pun (2009), Friedman (2014) and Yang (2015).

${ }^{3}$ Only in June 2018, the Cambodian authorities passed a Minimum Wage Law to lay the foundations for an "universal minimum wage" to be determined every year through "tripartite consultation" (Khmer Time, June 8, 2018).

${ }^{4}$ Although some scholars have pointed out that the official union is far from a uniform entity (Liu, Li, and Kim 2011) and there is a growing body of literature that studies Chinese experiments with union democracy at the company level (Chan 2015), the ACFTU is generally looked upon as an inefficient body, especially when it comes to representing the rights and interests of its supposed constituency. In light of this, some scholars have even raised doubts about whether the ACFTU should be considered a union at all (Taylor and Li 2007). 